Images

\title{
Fournier gangrene: rapid diagnosis with bedside ultrasonography
}

\author{
Jason D. Heiner, MD; Katisha Baldwin, MD; Brooks Laselle, MD
}

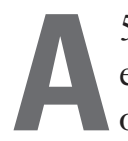

57-year-old woman with diabetes presented to the emergency department (ED) with a 3-day history of fever. Her blood pressure was $100 / 67 \mathrm{~mm} \mathrm{Hg}$, her heart rate was 99 beats/min and her temperature was $38.5^{\circ} \mathrm{C}$. Physical examination revealed tender, mildly erythematous skin extending from the mons pubis to the right labia majora without fluctuance or crepitus. Bedside ultrasonography revealed subcutaneous air (Fig. 1A) compatible with Fournier gangrene. The patient was given clindamycin, gentamicin and vancomycin, and was transported to the operating room within 1 hour of bedside ultrasonography. A CT scan requested for operative planning was obtained en route to the operating room (Fig. 1B).

Fournier gangrene is a necrotizing fasciitis of the perineum and genital areas typically caused by a polymicrobial mix of anaerobic and aerobic organisms. Predisposing risk factors include diabetes, alcohol abuse, renal failure, advancing age, malignancy and other immunocompromised states. Causes include anorectal, urinary and cutaneous sources. ${ }^{1}$ The pathognomonic "gas gangrene" with associated crepitus may spread at a rate of $2-3 \mathrm{~cm}$ per hour, leading to rapid tissue necrosis and significant morbidity and mortality. ${ }^{2}$ Prompt treatment including resuscitation, aggressive antibiotic therapy and extensive surgical débridement are critical. ${ }^{1}$

Whereas CT is now considered the gold standard for diagnosis and for evaluating the extent of the disease, bedside ultrasonography offers the possibility of earlier initiation of antibiotics as well as providing a diagnosis in less obvious cases. Typical findings on ultrasonography are marked tissue thickening and focal hyperechoic
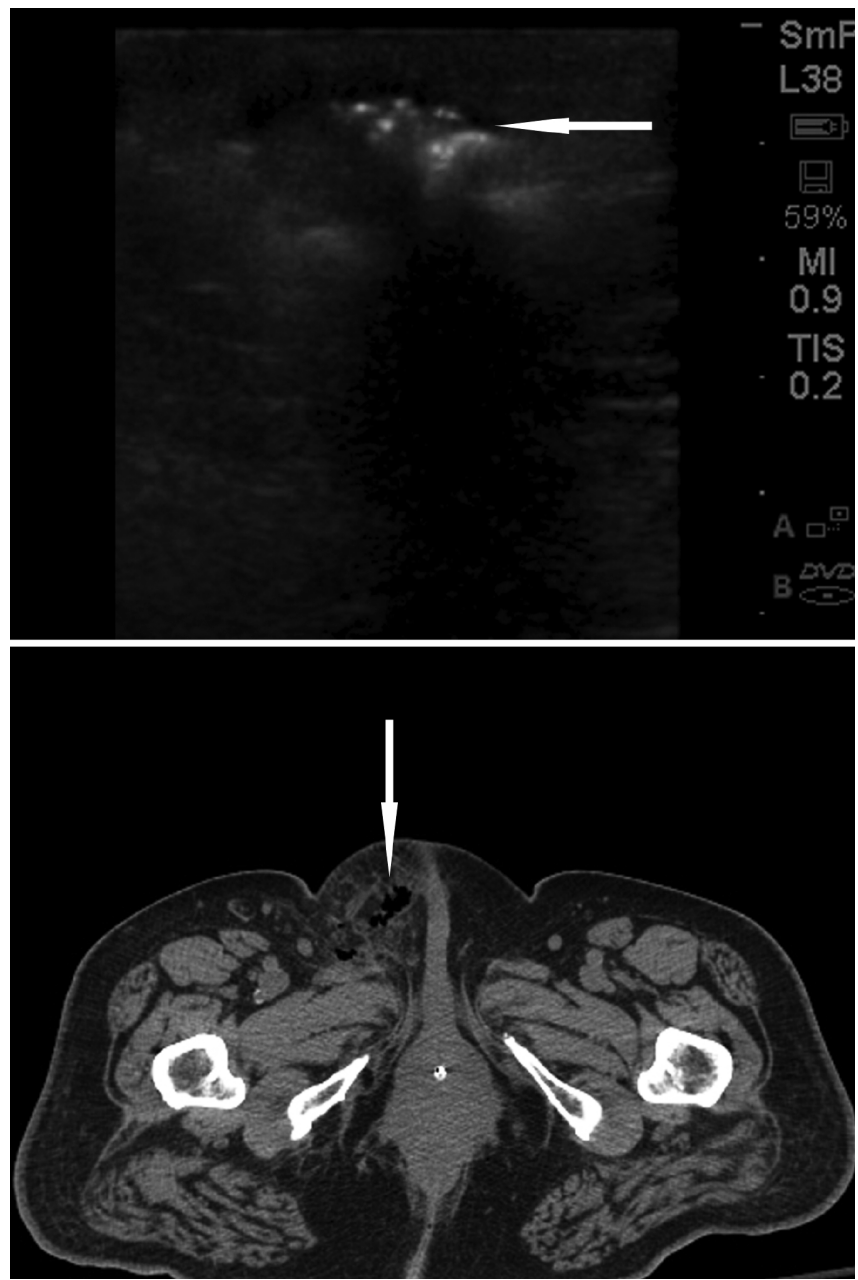

Fig. 1. (A) Bedside ultrasonography image of a 57-year-old woman showing gas as hyperechoic (white) regions that produce scatter. (B) CT scan showing gas as hypodense (black) areas.

From the Department of Emergency Medicine, Madigan Army Medical Center, Tacoma, Wash.

The views expressed herein are solely those of the authors and do not represent the official views of the US Department of Defense or the US Army Medical Department.

Submitted Dec. 14, 2009; Accepted Mar. 14, 2010

This article has been peer reviewed. 
areas with acoustic shadowing that scatter ultrasound and are indicative of subcutaneous air. ${ }^{3}$ Ultrasonography has been shown to diagnose subcutaneous air before crepitus is present on physical examination, and can aid in distinguishing Fournier gangrene from a more benign cellulitis. ${ }^{3}$ Prompt diagnosis by bedside ultrasonography may lead to more rapid interventions and decreased mortality from this threatening disease.

Competing interests: None declared.

Keywords: Fournier gangrene, ultrasonography, diagnosis

\section{REFERENCES}

1. Norton KS, Johnson LW, Perry T, et al. Management of Fournier's gangrene: an eleven year retrospective analysis of early recognition, diagnosis and treatment. Am Surg 2002;68:709-13.

2. Levenson RB, Singh AK, Novelline RA. Fournier gangrene: role of imaging. Radiographics 2008;28:519-28.

3. Kane CJ, Nash P, McAninch JW. Ultrasonographic appearance of necrotizing gangrene: aid in early diagnosis. Urology $1996 ; 48: 142-4$.
Correspondence to: Dr. Jason Heiner, Department of Emergency Medicine, Madigan Army Medical Center, 9040 Fitzsimmons Ave.,

Tacoma WA 98431; jasonheiner@hotmail.com

\section{LOOKING FOR A NEW JOB? LOOKING FOR AN EMERG DOc?}

In print and online, the best way to advertise or find employment opportunities in academic, administrative or community emergency medicine is through the Canadian Journal of Emergency Medicine.

Print version of CJEM: The deadline for advertising in the print version of $C J E M$ is one month before issue date. For ad rates and further information, please contact Journal Advertising (800 663-7336 or 613 731-8610; advertising@cma.ca).
SPECIAL BONUS: As a bonus to print advertisers, CJEM is pleased to offer website advertising space on CAEP's website (www.caep.ca) free of charge.

CAEP website alone: Advertising in the CAEP website alone is billed at a rate of $\$ 100$ a month, and can be obtained at any time. Please contact CAEP's Head Office for advertising solely on the website (800463-1158 or advertising@caep.ca).

\section{À LA RECHERCHE D'UN NOUVEL EMPLOI? À LA RECHERCHE D'UN MÉDECIN D'URGENCE?}

En version imprimée et en ligne, la meilleure façon de placer une annonce ou de trouver un emploi en médecine d'urgence dans un contexte universitaire, administratif ou communautaire est par le biais du Journal canadien de la médecine d'urgence.

Version imprimée du $\mathcal{J C M U}$ : la date butoir pour placer une annonce dans la version imprimée du JCMU est un mois avant la date de parution de la revue. Annonces publicitaires (800 663-7336 ou 613 731-8610; advertising@cma.ca).
PRIME SPÉCIALE : Les médecins qui placeront une annonce dans la version imprimée du JCMU recevront sans frais un espace pour leur annonce sur le site web de l'ACMU (www.caep.ca).

Site web de l'ACMU seulement : Pour placer une annonce sur le site web de l'ACMU seulement, le coût est de 100 \$ par mois et l'annonce peut être placée en tout temps. Veuillez communiquer avec le siège social de l'ACMU pour les annonces sur le site web seulement (800 463-1158 ou advertising@caep.ca). 